BASINDO : Jurnal Kajian Bahasa, Sastra Indonesia, dan Pembelajarannya

Volume 3 Nomor 1, 2019

Journal homepage $:$ http://journal2.um.ac.id/index.php/basindo

\title{
PENGARUH PENGGUNAAN MEDIA SOSIAL INSTAGRAM TERHADAP KEMAMPUAN MENULIS CERPEN SISWA KELAS X SMA ISLAM DIPONEGORO WAGIR
}

\author{
Sandra Yoga Pratama*, Siti Cholisotul Hamidah \\ Universitas Negeri Malang, Jalan Semarang 5 Malang
}

\begin{tabular}{|c|c|}
\hline $\begin{array}{l}\text { A R T I C L E } \\
\text { I N F O }\end{array}$ & A B S TRACT \\
\hline $\begin{array}{l}\text { Article history: } \\
\text { Received: } 31 \text { May } 2018 \\
\text { Accepted: } 18 \text { Jul } 2018 \\
\text { Published: } 31 \text { May } 2019 \\
\text { Kata Kunci: } \\
\text { media sosial, } \\
\text { keterampilan menulis } \\
\text { cerpen } \\
\text { Keyword: } \\
\text { social media, the ability to } \\
\text { write short story }\end{array}$ & $\begin{array}{l}\text { Tujuan penelitian ini adalah menjelaskan pengaruh media sosial } \\
\text { instagram terhadap kemampuan menulis cerpen yang meliputi (1) } \\
\text { pemilihan tema, (2) pemilihan alur, (3) penempatan tokoh, (4) } \\
\text { penggunaan latar, (5) penggunaan sudut pandang. Dari lima aspek } \\
\text { tersebut dapat diketahui seberapa berpengaruhnya media sosial } \\
\text { instagram terhadap kemampuan menulis cerpen. Penelitian ini jenis } \\
\text { penelitian eksperimen semu dengan pendekatan kualitatif. Populasi } \\
\text { pada penelitian ini adalah siswa kelas X SMA Islam Diponegoro } \\
\text { Wagir semester gasal tahun ajaran } 2017 / 2018 \text {. Pada penelitian ini } \\
\text { sampel yang dipilih adalah keseluruhan dari populasi dikarenakan } \\
\text { jumlah populasi kurang dari seratus. Instrumen penelitian ini berupa } \\
\text { tes menulis cerpen dengan ketentuan yang telah ditetapkan. Data } \\
\text { penelitian ini berupa skor kemampuan menulis cepen mencakup } \\
\text { skor tema, alur, tokoh, latar, dan sudut pandang. Pengumpulan data } \\
\text { dalam penelitian ini diperoleh dari hasil tes pretes dan postes. } \\
\text { Analisis data pada penelitian ini dilakukan dengan beberapa tahapan, } \\
\text { yaitu (1) uji persyaratan analisis yang terdiri dari uji normalitas dan uji } \\
\text { homogenitas, dan (2) uji hipotesis. }\end{array}$ \\
\hline & $\begin{array}{l}\text { The purpose of this study is explaining the influence of social media } \\
\text { instagram on short story writing ability include: (1) theme selection, } \\
\text { (2) plot selection, (3) character placement, (4) setting use, (5) point of } \\
\text { view use. From those aspects can be known how influential social } \\
\text { media instagram on the short story writing ability. This study is } \\
\text { quantitative with the kind of quasi-experimental research. The } \\
\text { population of this study is tenth grade students of SMA Islam } \\
\text { DiponegoroWagirgasal semester of } 2017 / 2018 \text {. This sample study is } \\
\text { the whole of population because the amount of population is less } \\
\text { from a hundred. This study instrument is test writing short story with } \\
\text { the conditions set. Study data is a score of short story writing ability. }\end{array}$ \\
\hline
\end{tabular}

\footnotetext{
* Corresponding author.

E-mail addresses: sndryp@gmail.com (Sandra Yoga Pratama)
}

ISSN : 2579-3799 (Online) - BASINDO : Jurnal Kajian Bahasa, Sastra Indonesia, dan Pembelajarannya is licensed under Creative Commons Attribution-ShareAlike 4.0 International License (http://creativecommons.org/licenses/BY/4.0/).

13 | BASINDO : Jurnal Kajian Bahasa, Sastra Indonesia, dan Pembelajarannya 
Includes theme, plot, character, setting, and pint of view. Data submitting in this study obtained from the result of pre-test and posttest. Data analysis in this study is done by several steps, there are (1) test requirements analysis consist of normality test and homogeneity test, (2) hypotheses test.

\section{PENDAHULUAN}

Dalam kegiatan pembelajaran, media adalah segala sesuatu yang digunakan oleh guru untuk menyampaikan materi pelajaran kepada murid, sehingga murid tertarik minat dan perhatiannya serta terangsang pikiran dan perasaannya pada kegiatan belajar dalam rangka mencapai tujuan pembelajaran (Shinta, Chamalah, \& Arsanti, 2018). Apapun media yang dipilih, guru harus mampu menggunakan media tersebut. Nilai dan manfaat media pembelajaran sangat ditentukan oleh bagaimana keterampilan guru menggunakan media pembelajaran tersebut. Keterampilan penggunaan media pembelajaran ini juga nantinya dapat diturunkan kepada siswa sehingga siswa juga mampu terampil menggunakan media pembelajaran yang dipilih.

Dewasa ini media sosial hampir menjadi kebutuhan setiap manusia, tidak bisa dipungkiri karena semakin berkembangnya teknologi semakin banyak orang yang tergiur akan fitur yang diberikan media sosial itu. Tidak heran jika saat ini para remaja menggandrungi media sosial, khususnya di kalangan pelajar SMA. Media sosial mengajak siapa saja yang tertarik untuk berpartisipasi dengan memberi kontribusi dan feedback secara terbuka, memberi komentar, serta membagi informasi dalam waktu yang cepat dan tak terbatas. Saat teknologi internet dan mobile phone makin maju maka media sosial pun ikut tumbuh dengan pesat. Demikian cepatnya orang bisa mengakes media sosial mengakibatkan terjadinya fenomena besar terhadap arus informasi tidak hanya di negara-negara maju, tetapi juga di Indonesia. Karena kecepatannya media sosial juga mulai tampak menggantikan peranan media massa konvensional dalam menyebarkan beritaberita. Instagram dapat diakses di mana saja dan kapan saja melalui mobile phone.

Instagram adalah suatu alat penyampaian pesan (aplikasi) untuk berkomunikasi dengan khalayak secara luas dengan saling berbagi foto atau video, yang di dalamnya juga terdapat fiturfitur lain seperti instastory, DM (direct message), komentar, suka dan sebagainya. Makin populernya Instagram sebagai aplikasi yang digunakan untuk membagi foto membuat banyak pengguna selalu ingin eksis dan terlihat kekinian dengan mengunggah setiap kegiatan yang dilakukan ke instagram dan selalu update supaya tidak ketinggalan jaman.

Dengan kenyataan yang seperti itulah penulis mencoba untuk memanfaatkan media sosial (instagram) sebagai stimulus untuk menulis cerpen siswa kelas X. Dengan mereka mengakses instagram mereka akan menyaksikan beberapa gambar dan video yang mereka akses melalui instagram dan secara tidak langsung di dalam otak mereka akan merekam dan menyimpan beberapa gambar atau video yang menurut mereka berkesan. Dengan begitu maka mereka lebih mempunyai banyak inspirasi cerita sehingga cerpen yang dihasilkan siswa akan semakin hidup dan lebih inovatif.

Menulis merupakan kegiatan menuangkan ide, pikiran, dan kemauan dengan wahana bahasa tulis (Nurchasanah, 1993:1). Tarigan (1994:3) menyatakan bahwa menulis merupakan suatu keterampilan berbahasa yang digunakan untuk berkomunikassi secara tidak langsung dan tidak secara bertatap muka dengan orang lain. Dari pendapat di atas penulis menyimpulkan menulis adalah kegiatan menyampaikan gagasan atau informasi kepada pembaca dalam bentuk tulisan.

Cerpen banyak diketahui dan dinikmati banyak orang. Namun, banyak para ahli yang pendapatnya berbeda-beda tentang cerpen. Cerita pendek merupakan cerita fiksi, namun dalam realita penulisan cerpen, banyak orang yang menulis cerpen berawal dari kisah nyata, baik yang dialami penulis atau orang lain. Menurut Sehandi (2016:53) karya sastra prosa memiliki karateristik sendiri dibandingkan dengan dua jenis karya sastra yang lain, yakni puisi dan drama. Pertama, karya sastra prosa bersifat cerita, bercerita. Lewat karyanya itu, pengarang berusaha 
menggambarkan seluruh ungkapan perasaan dan pikirannya ke dalam kejadian dan peristiwa serta jalan hidup tokoh-tokoh ceritanya dibeberkan sedemikian rupa secara terperinci. Setapak demi setapak pembaca dituntun mengikuti jalan cerita dari awal hingga akhir. Kedua, karya sastra prosa dibeberkan dalam bentuk bagian-bagian. Dalam mengemukakan ceritanya, pengarang tidak membeberkan sekaligus, melainkan dalam bentuk kesatuan-kesatuan yang padu, saling berkaitan membentuk kesatuan yang lebih besar, dan lebih besar lagi, sampai membentuk kesatuan cerita yang utuh dan lengkap. Ketiga, karya sastra prosa menggunakan bahasa biasa, namun juga bisa mengembangkan imajinasi para pembaca karena kepiawaian teknik penceritaan pengarang yang menarik dan menggugah. Berbeda dengan bahasa puisi yang padat ringkas penuh symbol dan kiasan yang bersifat konotatif dan imajinatif.

Dari uraian pendapat di atas dapat disimpulkan cerpen adalah sebuah prosa pendek dan hanya memusatkan perhatian pada tokoh utama di mana permasalahan yang paling menonjol akan menjadi dasar atau tema cerita tersebut. Pendek sebuah cerpen memang bukan mutlak ditentukan oleh sedikitnya halaman cerita atau ditentukan oleh sedikitnya jumlah tokoh yang ditampilkan, tetapi terletak pada ruang lingkup permasalahan yang ingin disampaikan pengarang lewat karyanya. Di berbagai negara yang memiliki tradisi sastra dalam bahasa Inggris, dikenal istilah short short-story (cerita pendek yang pendek) long short-story (cerita pendek yang panjang). Sebuah cerpen yang baik memiliki unsur-unsur intrinsik sebagaimana halnya dengan karya sastra prosa lain, yaitu (1) tema, (2) tokoh atau perwatakan, (3) alur, (4) plot, (5) latar atau seting, (6) diksi atau gaya bahasa.

\section{METODE}

Penelitian ini merupakan penelitian kuantitatif dengan jenis penelitian eksperimen murni (true elesperimental) karena desain ini peneliti mengontrol variabel luar yang memengaruhi jalannya eksperimen. Ciri dari eksperimen murni adalah sampel yang digunakan untuk kelompok kontrol dan kelompok eksperimen diambil secara acak dari populasi tertentu. Menurut Sugiyono (2011:7) penelitian kuantitatif adalah penelitian yang datanya berupa angka-angka dan dianalisis menggunakan statistik. Pendekatan kuantitatif digunakan untuk mengetahui seberapa seberapa besar pengaruh perlakuan tertentu dengan data berupa angka. Data yang diperoleh akan dianalisis menggunakan rumus statistika. Penelitian ini bertujuan untuk mengetahui pengaruh media sosial instagram terhadap kemampuan menulis cerpen siswa SMA.

Populasi pada penelitian ini adalah siswa kelas X SMA Islam Diponegoro Wagir semester gasal tahun ajaran 2017/2018 yang terdiri atas kelas 2 kelas. Sampel dalam penelitian ini menggunakan dua kelas X yang merupakan kelas homogen. Pada penelitian ini sampel yang dipilih adalah keseluruhan dari populasi dikarenakan jumlah populasi kurang dari seratus yang terdiri dari siswa kelas XA dan kelas XB. Siswa kelas XA merupakan kelas eksperimen dan siswa kelas XB merupakan kelas kontrol. Penentuan sampel pada penelitian ini menggunakan teknik sampling pupposive. Sampling purposive adalah teknik menentukan sampel dengan pertimbangan tertentu (Sugiyono 2011:85).

\section{HASIL}

\section{Kemampuan Mengembangkan Tema Cerpen dengan Menggunakan Media Sosial Instagram}

Tema adalah gagasan atau ide yang mendasari suatu karya. Rampan (2009:3) menyatakan dalam menulis karyanya, pengarang bukan sekedar bercerita, tetapi mengatakan sesuatu kepada pembacanya. Kemampuan mengembangkan tema dengan menarik harus dimiliki dalam menulis cerpen. Berdasarkan pembelajaran yang telah dilaksanakan pada kelas eksperimen dan kelas kontrol diperoleh hasil nilai kemampuan siswa pada aspek tema untuk kelas eksperimen nilai ratarata sebesar 14,75 dengan standar deviasi 4,128 dan pada kelas kontrol sebesar 12,50 dengan standar deviasi 2,988. 
Setelah dilaksanakan pretes, maka pembelajaran antara dua kelas diberikan perlakuan yang berbeda. Pembelajaran menulis cerpen dalam kelas eksperimen menggunakan media sosial instagram sedangkan pada kelas kontrol tidak menggunakan media sosial instagram. Dari hasil perhitungan tersebut, diketahui bahwa nilai rata-rata postes pada kelas eksperimen lebih tinggi dibandingkan dengan kelas kontrol. Hal ini menunjukkan bahwa media sosial instagram efektif digunakan dalam meningkatkan kemampuan mengembangkan tema dalam cerpen yang ditulis siswa.

\section{Kemampuan Mengembangkan Alur Cerpen dengan Menggunakan Media Sosial Instagram}

Alur adalah susunan peristiwa yang telah membentuk cerita. Alur yang ditampilkan dalam cerita bersifat sederhana karena peristiwa tersebut berdasarkan kaitan sebab akibat. Alur sebuah cerita haruslah padu, logis, dan jelas antara peristiwa yang satu dan yang lain. Sumardjo (2007:136) mengungkapkan bahwa sebuah alur bisa menelurkan beberapa jalan cerita. Kemampuan mengembangkan alur dengan menarik harus dimiliki dalam menulis cerpen. Berdasarkan pembelajaran yang telah dilaksanakan pada kelas eksperimen dan kelas kontrol diperoleh hasil nilai kemampuan siswa pada aspek alur untuk kelas eksperimen nilai rata-rata sebesar 16,25 dengan standar deviasi 2,751 dan pada kelas kontrol sebesar 13,18 dengan standar deviasi 3,634.

Setelah dilaksanakan pretes, maka pembelajaran antara dua kelas diberikan perlakuan yang berbeda. Pembelajaran menulis cerpen dalam kelas eksperimen menggunakan media sosial instagram sedangkan pada kelas kontrol tidak menggunakan media sosial instagram. Dari hasil perhitungan tersebut, diketahui bahwa nilai rata-rata postes pada kelas eksperimen lebih tinggi dibandingkan dengan kelas kontrol. Hal ini menunjukkan bahwa media sosial instagram efektif digunakan dalam meningkatkan kemampuan mengembangkan alur dalam cerpen yang ditulis siswa.

\section{Kemampuan Mengembangkan Tokoh Cerpen dengan Menggunakan Media Sosial Instagram}

Tokoh merupakan pelaku yang mengemban peristiwa dalam cerita fiksi sehingga peristiwa itu mampu menjalin suatu cerita. Istilah tokoh mengacu pada orangnya, pelaku cerita. Jika disimpulkan maka tokoh cerita adalah individu rekaan yang mempunyai watak dan perilaku tertentu sebagai pelaku yang mengalami peristiwa dalam cerita. Aminuddin (2013: 80) mengemukakan bahwa di dalam cerpen tokoh yang memiliki watak baik sehingga disenangi pembaca disebut tokoh protagonis. Berbeda dengan tokoh protagonis, tokoh antagonis adalah tokoh yang tidak sesuai dengan apa yang diidamkan pembaca.

Berdasarkan pembelajaran yang telah dilaksanakan pada kelas eksperimen dan kelas kontrol diperoleh hasil nilai kemampuan siswa pada aspek tokoh untuk kelas eksperimen nilai rata-rata sebesar 14,00 dengan standar deviasi 3,479 dan pada kelas kontrol sebesar 11,14 dengan standar deviasi 3,427.

Setelah dilaksanakan pretes, maka pembelajaran antara dua kelas diberikan perlakuan yang berbeda. Pembelajaran menulis cerpen dalam kelas eksperimen menggunakan media sosial instagram sedangkan pada kelas kontrol tidak menggunakan media sosial instagram. Dari hasil perhitungan tersebut, diketahui bahwa nilai rata-rata postes pada kelas eksperimen lebih tinggi dibandingkan dengan kelas kontrol. Hal ini menunjukkan bahwa media sosial instagram efektif digunakan dalam meningkatkan kemampuan mengembangkan tokoh dalam cerpen yang ditulis siswa.

\section{Kemampuan Mengembangkan Latar Cerpen dengan Menggunakan Media Sosial Instagram}

Latar adalah lingkungan tempat peristiwa itu terjadi. Rokhmansyah (2014: 38) menjelaskan bahwa latar adalah lingkungan tempat peristiwa itu terjadi. Latar dalam arti yang 
lengkap meliputi aspek ruang dan waktu terjadinya peristiwa, serta aspek suasana. Berdasarkan pembelajaran yang telah dilaksanakan pada kelas eksperimen dan kelas kontrol diperoleh hasil nilai kemampuan siswa pada aspek latar untuk kelas eksperimen nilai rata-rata sebesar 17,00 dengan standar deviasi 3,513 dan pada kelas kontrol sebesar 13,64 dengan standar deviasi 3,513.

Setelah dilaksanakan pretes, maka pembelajaran antara dua kelas diberikan perlakuan yang berbeda. Pembelajaran menulis cerpen dalam kelas eksperimen menggunakan media sosial instagram sedangkan pada kelas kontrol tidak menggunakan media sosial instagram. Dari hasil perhitungan tersebut, diketahui bahwa nilai rata-rata postes pada kelas eksperimen lebih tinggi dibandingkan dengan kelas kontrol. Hal ini menunjukkan bahwa media sosial instagram efektif digunakan dalam meningkatkan kemampuan mengembangkan latar dalam cerpen yang ditulis siswa.

\section{Kemampuan Mengembangkan Sudut Pandang Cerpen dengan Menggunakan Media Sosial Instagram}

Sudut pandang adalah posisi yang menjadi pusat kesadaran tempat untuk memahami setiap peristiwa dalam cerita. Suroto (1990:96) menyatakan bahwa sudut pandang di sini adalah kedudukan atau posisi pengarang dalam cerita tersebut. Sudut pandang yang digunakan pengarang pada karyanya merupakan cara pengarang untuk menceritakan cerita dalam karyanya. Berdasarkan pembelajaran yang telah dilaksanakan pada kelas eksperimen dan kelas kontrol diperoleh hasil nilai kemampuan siswa pada aspek latar untuk kelas eksperimen nilai rata-rata sebesar 18,00 dengan standar deviasi 2,513 dan pada kelas kontrol sebesar 15,68 dengan standar deviasi 2,801 .

Setelah dilaksanakan pretes, maka pembelajaran antara dua kelas diberikan perlakuan yang berbeda. Pembelajaran menulis cerpen dalam kelas eksperimen menggunakan media sosial instagram sedangkan pada kelas kontrol tidak menggunakan media sosial instagram. Dari hasil perhitungan tersebut, diketahui bahwa nilai rata-rata postes pada kelas eksperimen lebih tinggi dibandingkan dengan kelas kontrol. Hal ini menunjukkan bahwa media sosial instagram efektif digunakan dalam meningkatkan kemampuan mengembangkan sudut pandang dalam cerpen yang ditulis siswa.

\section{Uji Normalitas}

Uji normalitas dilakukan untuk mengetahui apakah data yang diuji berdistribusi normal atau tidak. Uji normalitas diperlikan untuk melakukan ujian variabel lainnya dengan mengasumsikan bahwa nilai yang diuji berdistribusi normal. Jika data yang diuji berdistribusi normal, uji-t dapat dilanjutkan. Hasil perhitungan statistik menggunakan program SPSS 16 for Windows diperoleh nilai signifikansi kelompok eksperimen dengan responden masing-masing 20 siswa pada pretes sebesar 0,520 dan postes sebesar 0,204. Berdasarkan distribusi normalitas maka signifikansi 0,520 >0,05 dan 0,204 >0,05. Dengan demikian, disimpulkan bahwa nilai kelompok eksperimen pada pretes dan postes berdistribusi normal.

Hasil perhitungan statistik menggunakan program SPSS 16 for Windows diperoleh nilai signifikansi kelompok kontrol dengan responden masing-masing 22 siswa pada pretes sebesar 0,215 dan postes sebesar 0,500. Berdasarkan distribusi normalitas maka signifikansi 0,215 $>0,05$ dan $0,500>0,05$. Dengan demikian, disimpulkan bahwa nilai kelompok eksperimen pada pretes dan postes berdistribusi normal.

\section{Uji Homogenitas}

Uji homogenitas digunakan untuk mengetahui tingkat homogenitas data yang diuji menggunakan uji-t. Kriteria pengujian homogenitas data adalah jika signifikansi $>0,05$ maka data homogen. Jika signifikansi $<0,05$ maka data tidak homogen. Pada kelas eksperimen dan kelas kontrol menentukan nilai pada tahap pretes dengan responden masing-masing 42 siswa sebesar 0,375 dan pada tahap postes 0,106. Berdasarkan kriteria homogenitas data, maka signifikansi 
$0,375>0,05$ dan 0,106 $>0,05$. Dapat disimpulkan bahwa distribusi dari kedua kelas tersebut pada tahap pretes dan postes menunjukkan kedua kelas tersebut homogen.

\section{PEMBAHASAN}

\section{Pengaruh Penggunaan Media Sosial Instagram terhadap Kemampuan Menulis Cerpen Pada Aspek Tema}

Berdasarkan hasil analisis diketahui bahwa terdapat pengaruh penggunaan media sosial instagram terhadap kemampuan menulis siswa pada aspek tema. Hal ini dapat dilihat dari hasil analisis yang telah dilakukan menggunakan uji-t dengan bantuan SPSS 16.0 for Windows dengan uji Independent Sample T Test, diperoleh nilai signifikansi $<0,05$, yaitu 0,048. Jika taraf signifikansi $<$ 0,05 , hal itu menunjukkan adanya perbedaan atau pengaruh. Rata-rata yang diperoleh kelompok eksperimen adalah 14,75 dan kelompok kontrol 12,50. Dari hasil tersebut dapat diketahui bahwa rata-rata kelompok eksperimen lebih tinggi dibandingkan dengan kelompok kontrol. Hal tersebut disebabkan oleh perlakuan yang berbeda. Kelompok eksperimen mendapatkan perlakuan dengan menggunakan media sosial instagram, sedangkan untuk kelas kontrol tidak diberi perlakuan.

Siswa kelompok eksperimen yang diberi perlakuan berupa media sosial instagram mendapatkan stimulus yang baik sehingga siswa dapat mengeksplor dan menentukan tema yang kreatif kemudian diterapkan dan dikembangkan ke dalam cerpen yang mereka karyakan.

Berikut kutipan cerpen dari kelompok eksperimen yang memiliki tema kekinian.

"Aku ingin seperti HP!" mengapa? Karena setiap HP berbunyi Ibu cepat-cepat mengangkat, sedangkan jika aku yang memanggil selalu dicuekin sampai-sampai lupa kalau aku belum makan juga belum mandi.

(Riska, kelas eksperimen)

\section{Gara-gara Game Online}

Pada saat itu dia pergi keluar rumah mencari teman-temannya untuk diajak bermain game online. Saat itu dia hendak menyebrang jalan tetapi dia tidak melihat kanan dan kiri malah melihat HP yang dia pegang.

(Elisawati, kelas eksperimen)

Berdasarkan kutipan (1) dan (2) menunjukkan jika cerpen yang dibuat bersifat kekinian. Hal tersebut dapat dilihat pada kutipan (1) yang menceritakan rasa cemburunya terhadap HP. Sedangkan pada kutipan (2) juga menceritakan bagaimana HP bisa melalaikan segalanya. Tidak bisa dipungkiri lagi jika jaman sekarang HP sudah menjadi barang wajib dan hamper dimiliki semua orang. Sehingga tidak sedikit orang yang lebih mementingkan HP daripada hal yang lainnya.

\section{Pengaruh Penggunaan Media Sosial Instagram terhadap Kemampuan Menulis Cerpen Pada Aspek Alur}

Berdasarkan hasil analisis diketahui bahwa terdapat pengaruh penggunaan media sosial instagram terhadap kemampuan menulis siswa pada aspek alur. Hal ini dapat dilihat dari hasil analisis yang telah dilakukan menggunakan uji-t dengan bantuan SPSS 16.0 for Windows dengan uji Independent Sample T Test, diperoleh nilai signifikansi $<0,05$, yaitu 0,004. Jika taraf signifikansi $<$ 0,05 , hal itu menunjukkan adanya perbedaan atau pengaruh. Rata-rata yang diperoleh kelompok eksperimen adalah 16,25 dan kelompok kontrol 13,18. Dari hasil tersebut dapat diketahui bahwa rata-rata kelompok eksperimen lebih tinggi dibandingkan dengan kelompok kontrol. Hal tersebut disebabkan oleh perlakuan yang berbeda. Kelompok eksperimen mendapatkan perlakuan dengan menggunakan media sosial instagram, sedangkan untuk kelas kontrol tidak diberi perlakuan.

Siswa kelompok eksperimen yang diberi perlakuan berupa media sosial instagram mendapat stimulus yang baik sehingga siswa dapat menyusun alur dengan baik dan menarik. Alur 
dalam cerpen dapat memengaruhi kemenarikan cerpen dengan cara mempermainkan cerita di dalam cerpen yang sengaja dibawa ke fase yang rumit terlebih dulu sampai dengan penyelesaian.

Berikut kutipan cerpen dari kelompok eksperimen yang memunculkan konflik dari cerpen yang ditulis dengan sedikit lebih rumit.

\section{"Kasih Sepanjang Masa"}

Keesokan hari Tiara dibawa ke rumah sakit karena keadaannya yang semakin memburuk. Dan di situ Sintia memulai menyadari kalau dia sangat mengabaikan adiknya, dan dia juga mengingat bahwa dua hari lagi adalah hari ulang tahun sang adik. Sintia berusaha menghubungi kedua orang tuanya tetapi mereka masih tetap mengabaikan dan tidak mau tahu.

Hampir sehari dirawat di rumah sakit Tiara masih saja belum sadar dari komanya, itu membuat Sintia menjadi sangat khawatir. Hingga waktu menunjukkan pukul 12 malam, dan di situ tepat hari ulang tahun Tiara yang ke 10 tahun. Sintia memeluk tubuh sang adik yang masih tertidur koma sambil menangis tersedu-sedu. Pagi harinya Tiara sadar, Sintia sangat senang dan memanggil dokter.

(Susi Elisa, kelas eksperimen)

Berdasarkan kutipan di atas menunjukkan jika cerpen yang dibuat memunculkan konflik dari cerpen yang ditulis dengan sedikit lebih rumit. Hal tersebut dapat dilihat pada kutipan cerpen yang berjudul "Kasih Sepanjang Masa" menceritakan Tiara yang sedang sakit dan harus dilarikan ke rumah sakit, tetapi ia tak kunjung membaik menjelang hari ulang tahunnya yang ke 10 tahun. Hal itu membuat Sintia khawatir dengan keadaan Tiara. Sintia berusaha menghubungi kedua orang tuanya namun mereka masih tetap mengabaikan karena kesibukannya. Dari cerita tersebut penulis membuat pembaca bertanya-tanya apakah Tiara akan segera sadar dan bagaimana kedua orang tuanya. Hal tersebut menunjukkan jika konflik yang disajikan penulis cukup rumit untuk diselesaikan, dan hal tersebut membuat pembaca penasaran. Dengan ini penulis berhasil membuat pembaca penasaran dengan kelanjutan ceritanya.

\section{Pengaruh Penggunaan Media Sosial Instagram terhadap Kemampuan Menulis Cerpen Pada Aspek Tokoh}

Berdasarkan hasil analisis diketahui bahwa terdapat pengaruh penggunaan media sosial instagram terhadap kemampuan menulis siswa pada aspek tokoh. Hal ini dapat dilihat dari hasil analisis yang telah dilakukan menggunakan uji-t dengan bantuan SPSS 16.0 for Windows dengan uji Independent Sample T Test, diperoleh nilai signifikansi $<0,05$, yaitu 0,010. Jika taraf signifikansi $<$ 0,05 , hal itu menunjukkan adanya perbedaan atau pengaruh. Rata-rata yang diperoleh kelompok eksperimen adalah 14,00 dan kelompok kontrol 11,14. Dari hasil tersebut dapat diketahui bahwa rata-rata kelompok eksperimen lebih tinggi dibandingkan dengan kelompok kontrol. Hal tersebut disebabkan oleh perlakuan yang berbeda. Kelompok eksperimen mendapatkan perlakuan dengan menggunakan media sosial instagram, sedangkan untuk kelas kontrol tidak diberi perlakuan.

Siswa kelompok eksperimen yang diberi perlakuan berupa media sosial instagram dengan siswa kelompok kontrol yang tidak diberi perlakuan sama-sama memaparkan tokoh secara sentral di mana tokoh protagonis dan antagonis lebih banyak mengalami peristiwa dalam cerita. Perbedaannya hanya pada penggunaan tokoh figuran, di mana pada kelas eksperimen penggunaan tokoh figuran lebih dimunculkan.

Berikut kutipan cerpen dari kelompok eksperimen yang memunculkan tokoh figuran.

"Oleh-Oleh HUT Sekolah"

Tanpa kusadari seseorang melihatku dengan tatapan yang lurus dan fokus. Aku menatapnya kembali, namun Dia salah tingkah, lucu sekali pipinya memerah. Ingin aku mendekatinya mengajaknya berkenalan, tetapi tidak jadi karena di sebelahnya Dia bersama seseorang perempuan, ya mungkin saja itu kekasihnya. Hari itu aku sangat kepedean sekali. Aku pulang dengan wajah muram.

(Dewi Kurniawati, kelas eksperimen) 
Berdasarkan kutipan di atas menunjukkan jika cerpen yang dibuat memunculkan tokoh figuran. Hal tersebut dapat dilihat pada kutipan cerpen yang berjudul "Oleh-Oleh HUT Sekolah" yang menceritakan tokoh Aku yang sedang memandang Dia, namun ada seseorang di sebelah Dia. Seseorang yang berada di sebelah Dia termasuk tokoh figuran karena hanya menjadi pelengkap cerita saja.

\section{Pengaruh Penggunaan Media Sosial Instagram terhadap Kemampuan Menulis Cerpen Pada Aspek Latar}

Berdasarkan hasil analisis diketahui bahwa terdapat pengaruh penggunaan media sosial instagram terhadap kemampuan menulis siswa pada aspek latar. Hal ini dapat dilihat dari hasil analisis yang telah dilakukan menggunakan uji-t dengan bantuan SPSS 16.0 for Windows dengan uji Independent Sample T Test, diperoleh nilai signifikansi $<0,05$, yaitu 0,001. Jika taraf signifikansi $<$ 0,05 , hal itu menunjukkan adanya perbedaan atau pengaruh. Rata-rata yang diperoleh kelompok eksperimen adalah 17,00 dan kelompok kontrol 13,64. Dari hasil tersebut dapat diketahui bahwa rata-rata kelompok eksperimen lebih tinggi dibandingkan dengan kelompok kontrol. Hal tersebut disebabkan oleh perlakuan yang berbeda. Kelompok eksperimen mendapatkan perlakuan dengan menggunakan media sosial instagram, sedangkan untuk kelas kontrol tidak diberi perlakuan.

Siswa kelompok eksperimen yang diberi perlakuan berupa media sosial instagram memberikan stimulus yang baik sehingga siswa dapat mengeksplor dan menentukan latar yang lebih lengkap dan bervariasi ke dalam cerpen yang mereka karyakan. lengkap.

Berikut kutipan cerpen dari kelompok eksperimen yang memunculkan latar secara

"Bidadari Bermata Bening"

Mereka berbincang-bincang menghangatkan susasana yang mencekam malam itu.

Tanpa disadari fajar terbit di ufuk timur. Ibu Layla beberapa hari terakhir ini kesehatannya begitu buruk. Mereka sholat subuh bersama. Begitu cepatnya kebersamaan Ibu dan Layla itu. Di sujud terakhirnya Ibu Layla pergi untuk selamanya. Layla begitu tak percaya dengan apa yang terjadi, semalam mereka masih bersama di dalam hangatnya rumah.

(Rika Rahmawati, kelas eksperimen)

Berdasarkan kutipan di atas menunjukkan jika cerpen yang dibuat memunculkan latar secara lengkap. Hal tersebut dapat dilihat pada kutipan cerpen yang berjudul "Bidadari Bermata Bening" ditandai dengan kalimat mereka berbincang-bincang menghangatkan susasana yang mencekam malam itu yang merupakan latar suasana dan latar waktu sekaligus. Sedangkan latar tempat ditunjukan pada kalimat Layla begitu tak percaya dengan apa yang terjadi, semalam mereka masib bersama di dalam hangatnya rumah.

\section{Pengaruh Penggunaan Media Sosial Instagram terhadap Kemampuan Menulis Cerpen Pada Aspek Sudut Pandang}

Berdasarkan hasil analisis diketahui bahwa terdapat pengaruh penggunaan media sosial instagram terhadap kemampuan menulis siswa pada aspek sudut pandang. Hal ini dapat dilihat dari hasil analisis yang telah dilakukan menggunakan uji-t dengan bantuan SPSS 16.0 for Windows dengan uji Independent Sample $T$ Test, diperoleh nilai signifikansi $<0,05$, yaitu 0,008. Jika taraf signifikansi $<0,05$, hal itu menunjukkan adanya perbedaan atau pengaruh. Rata-rata yang diperoleh kelompok eksperimen adalah 18,00 dan kelompok kontrol 15,68. Dari hasil tersebut dapat diketahui bahwa rata-rata kelompok eksperimen lebih tinggi dibandingkan dengan kelompok kontrol. Hal tersebut disebabkan oleh perlakuan yang berbeda. Kelompok eksperimen mendapatkan perlakuan dengan menggunakan media sosial instagram, sedangkan untuk kelas kontrol tidak diberi perlakuan.

Hasil karya siswa antara kelas kontrol dan kelas eksperimen juga tidak terlalu banyak perbedaan. Penempatan sudut pandang oleh kelas kontrol dan kelas eksperimen dalam cerita 
sudah cukup jelas. Namun ada satu atau dua cerpen hasil karya siswa kelas kontrol yang masih kurang jelas.

\section{Pengaruh Penggunaan Media Sosial Instagram terhadap Kemampuan Menulis Cerpen Secara Keseluruhan}

Penggunaan media sosial instagram berpengaruh terhadap kemampuan menulis siswa secara keseluruhan. Hal ini dapat dilihat dari hasil analisis yang telah dilakukan menggunakan uji-t dengan bantuan SPSS 16.0 for Windows dengan uji Independent Sample T Test, diperoleh nilai signifikansi $<0,05$, yaitu 0,031 . Jika taraf signifikansi $<0,05$, hal itu menunjukkan bahwa adanya perbedaan atau pengaruh. Rata-rata yang diperoleh kelompok eksperimen adalah 71,00 dan kelompok kontrol 64,32. Dari hasil tersebut dapat diketahui bahwa rata-rata kelompok eksperimen lebih tinggi dibandingkan dengan kelompok kontrol.

Pemberian media sosial instagram dirasa tepat dan sesuai untuk digunakan dalam proses pembelajaran. Hal ini didukung oleh Daryanto (2013:60) menyatakan bahwa dengan teknologi kita bisa belajar apa saja, kapan saja, dan di mana saja. Di Indonesia, meskipun teknologi belum digunakan secara luas namun cepat atau lambat teknologi ini akan diserap juga ke dalam system pembelajaran di sekolah.

Secara umum menulis cerpen merupakan suatu hal yang tidak mudah. Memang untuk beberapa siswa yang memiliki kreativitas tinggi memiliki beberapa kelebuhan dan kemudahan dalam menulis cerpen, tetapi untuk siswa yang kemampuannya biasa-biasa saja akan menjadi satu hal yang cukup sukar. Maka dari itu perlu adanya media pembelajaran yang dapat merangsang kreativitas siswa serta dapat menemukan inspirasi dalam menulis cerpen.

Media pada penelitian ini yaitu media sosial instagram yang berisikan unggahan dari akun di seluruh penjuru bumi. Unggahan yang mereka bagikan di jejaring sosial instagram berupa gambar dan video. Dengan begiu siswa dapat mengekslpor segala hal yang mereka suka. Hal tersebut digunakan sebagai stimulus kepada siswa untuk menghasilkan sebuah cerpen yang bervariasi. cerpen yang baik adalah cerpen yang orisinil dan membuat pembaca mengerti maksud dari penulis.

Dengan pemanfaatan media sosial instagram, siswa di kelompok eksperimen cenderung lebih memiliki banyak variasi dalam menulis cerpen dibandingkan kelas kontrol.

\section{PENUTUP}

\section{Simpulan}

Hasil penelitian pengaruh media sosial instagram terhadap kemampuan menulis cerpen pada aspek tema menunjukan nilai Asymp-Sig 0,048 $<0,05$ dan disimpulkan bahwa hipotesis alternatif yang menyatakan bahwa terdapat pengaruh signifikansi penggunaan media sosial instagram terhadap kemampuan menulis cerpen kelas X SMA Islam Diponegoro Wagir dengan nilai rata-rata pada kelompok eksperimen 14,75 dan kelas kontrol 12,50. Hasil penelitian pengaruh media sosial instagram terhadap kemampuan menulis cerpen pada aspek alur menunjukan nilai Asymp-Sig $0,004<0,05$ sehingga dapat disimpulkan bahwa hipotesis alternatif yang menyatakan bahwa terdapat pengaruh signifikansi penggunaan media sosial instagram terhadap kemampuan menulis cerpen kelas X SMA Islam Diponegoro Wagir dengan nilai rata-rata pada kelompok eksperimen 16,25 dan kelas kontrol 13,18. Hasil penelitian pengaruh media sosial instagram terhadap kemampuan menulis cerpen pada aspek tokoh menunjukan nilai Asymp-Sig 0,010<0,05 sehingga dapat disimpulkan bahwa hipotesis alternatif yang menyatakan bahwa terdapat pengarub signifikansi penggunaan media sosial instagram terhadap kemampuan menulis cerpen kelas X SMA Islam Diponegoro Wagir dengan nilai rata-rata pada kelompok eksperimen 14,00 dan kelas kontrol 11,14. Hasil penelitian pengaruh media sosial instagram terhadap kemampuan menulis cerpen pada aspek latar menunjukan nilai Asymp-Sig 0,001 <0,05 sehingga dapat disimpulkan bahwa hipotesis alternatif yang menyatakan bahwa terdapat pengaruh signifikansi penggunaan media sosial instagram terhadap kemampuan menulis cerpen kelas X SMA Islam Diponegoro W agir dengan nilai rata-rata pada kelompok eksperimen 17,00 
dan kelas kontrol 13,64. Hasil penelitian pengaruh media sosial instagram terhadap kemampuan menulis cerpen pada aspek sudut pandang menunjukan nilai Asymp-Sig 0,008 < 0,05 sehingga dapat disimpulkan bahwa hipotesis alternatif yang menyatakan bahwa terdapat pengaruh signifikansi penggunaan media sosial instagram terhadap kemampuan menulis cerpen kelas X SMA Islam Diponegoro Wagir dengan nilai rata-rata pada kelompok eksperimen 18,00 dan kelas kontrol 15,68.

Secara umum disimpulkan bahwa penggunaan media sosial instaram berpengaruh terhadap kemampuan menulis cerpen pada siswa kelas X SMA Islam Diponegoro Wagir. Pengaruh penggunaan media sosial instagram terhadap kemampuan menulis cerpen ini menunjukan nilai signifikan $<0,05$. Hasil penelitian pada pengaruh media sosial instagram terhadap kemampuan menulis cerpen menunjukan nilai Asymp-Sig 0,031 < 0,05 sehingga dapat disimpulkan bahwa hipotesis alternatif yang menyatakan bahwa terdapat pengarub signifikansi penggunaan media sosial instagram terhadap kemampuan menulis cerpen kelas X SMA Islam Diponegoro Wagir dengan nilai rata-rata pada kelompok eksperimen 71,00 dan kelas kontrol 64,32.

Pada penelitian ini media sosial instagram berfungsi sebagai stimulus proses keterampilan menulis cerpen yang mengarahkan perhatian dan menuntun cara berpikir siswa serta memungkinkan siswa menemukan ide baru pada media sosial instagram.

\section{Saran}

Berdasarkan hasil simpulan di atas, saran yang diberikan peneliti sebagai berikut.

1) Bagi guru bahasa Indonesia disarankan agar menjadikan hasil penelitian ini sebagai bahan pertimbangan untuk menggunakan teknologi sebagai media pembelajaran, khususnya media sosial instagram dalam pembelajaran menulis cerpen, karena penggunaan media dapat memberikan pengaruh yang baik atau manfaat dalam proses pembelajaran menulis cerpen.

2) Bagi peneliti selanjutnya disarankan agar menjadikan penelitian ini sebagai acuan dalam mengadakan penelitian sejenis pada aspek lain seperti unsure ekstrinsik cerpen yang mencakup unsur sosiologi, ideologi, histori, politik, ekonomi, kebudayaan, dan lain-lain. Peneliti selanjutnya juga diharapkan dapat mengadakan penelitian sejenis yang kemudian dikembangkan menjadi penelitian pengembangan.

3) Bagi siswa pembelajaran menulis cerpen menggunakan media sosial instagram yang diberikan disarankan agar dijadikan salah satu opsi media yang nantinya digunakan sebagai alat untuk memperoleh inspirasi dalam menyelesaikan tugas sekolah khususnya menulis cerpen atau yang berkaitan dengan sastra, sehingga dengan media sosial siswa juga bisa belajar serta menimbulkan dampak yang positif pada bidang pendidikan.

\section{DAFTAR PUSTAKA}

Aminuddin. (2013). Pengantar Apresiasi Karya Sastra. Bandung: Sinar Baru Algesindo

Nurchasanah dan Hs, Widodo. (1993). Keterampilan Menulis dan Pengajarannya. Malang: Universitas Negeri Malang.

Rampan, K L. (2009). Apresiasi Cerpen Indonesia Mutakbir. Jakarta: Bukupop.

Rokhmansyah, A. (2014). Studi dan Pengkajian Sastra. Semarang: Graha Ilmu.

Sehandi, Y. (2016). Mengenal 25 Teori Sastra. Yogyakarta: Penerbit Ombak.

Shinta, Y. D., Chamalah, E., \& Arsanti, M. (2018). PENERAPAN MODEL PEMBELAJARAN BERDASARKAN MASALAH DAN MEDIA VIDEO ANIMASI PERISTIWA SOSIAL BERMUATAN PENDIDIKAN MULTIKULTURAL UNTUK MENINGKATKAN KETERAMPILAN MENYUSUN TEKS EKSPLANASI.

BASINDO : jurnal kajian bahasa, sastra Indonesia, dan pembelajarannya, 1(2), 59-71.

Sugiyono. (2013). Metode Penelitian Pendidikan. Bandung: Alfabeta.

Sumardjo, J. (2007). Catatan Kecil tentang Menulis Cerpen. Yogyakarta: Pustaka Pelajar.

Tarigan, H. G. (1994). Membaca sebagai Suatu Keterampilan Berbabasa. Bandung: Penerbit Angkasa. 